\title{
Taxes, subsidies, regulation in dynamic models
}

\author{
Giacomo Corneo $^{1}$ - Sergio Vergalli ${ }^{2}$
}

Received: 13 July 2016 / Accepted: 13 July 2016 / Published online: 19 July 2016

(C) Springer-Verlag Wien 2016

The four articles in this special issue of the Journal of Economics are a selection of the papers presented at a October 2015 workshop on "Taxes, Subsidies, Regulation in Dynamic Models" at the University of Brescia. The workshop gathered scholars from around the world who have been investigating various issues in public economics through the lens of dynamic models.

The first two articles in this special issue, by Di Corato (2016) and Panteghini and Vergalli (2016), are devoted to the effects of taxes and subsidies on firms' investment activities. Both employ the theory of real options and demonstrate its fruitfulness for public economics. This theory studies the opportunity to invest in an irreversible project (as a financial call option) in which the investor has the possibility, for some amount of time, to invest (to pay an exercise price), in expectation of some future uncertain returns. The task of the investor is to select the optimal timing to act, which is determined within a dynamic stochastic model. ${ }^{1}$

The model developed by Di Corato mainly contributes to the literature that compares tax reductions and investment subsidies as alternative instruments to stimulate private investment initiative. One possibility is to subsidize the initial investment, and hence reduce its cost to the investor; the other is to reduce the taxes that are charged on future profits generated by the project. The existing literature on the comparison between subsidies and tax reduction suggests that the former pushes private investment stronger than the latter (e.g. Pennings 2005). In his paper, Di Corato examines the net benefit

\footnotetext{
1 See Dixit and Pindyck (1994) for an overview of the real option literature.

$凶 \quad$ Giacomo Corneo

Giacomo.Corneo@fu-berlin.de

1 Department of Economics, Free University of Berlin, Berlin, Germany

2 Department of Economics and Fondazione Eni Enrico Mattei, University of Brescia, Brescia, Italy
} 
that accrues to a present-biased government that wants to speed up investment using a tax cut on future profits or an investment subsidy as an incentive. The author shows that, depending on the degree of the government present-biasedness, it may be more advantageous for the government to provide a tax cut. A distinctive merit of this analysis is to consider the role played by the government's time preferences. This can shed light on the impact of intergenerational altruism and political turnover on decisions concerning the stimulation of domestic investment in specific industries or the attraction of foreign direct investments.

Panteghini and Vergalli (2016) focus on the effects of corporate taxation under default and systemic risk. In their model they study a representative firm that can decide when to invest. On the one hand, the firm can benefit from generous tax depreciation allowances; on the other hand, it faces a default risk. Their theoretical and numerical findings suggest that generous tax depreciation allowances lead to a decrease in a firm's leverage and, in most cases, to a reduction in the default risk. The strong policy implication is that an investment stimulus pack is expected neither to increase the default risk nor to cause financial instability. This paper thus complements the existing literature about the neutrality properties of taxation in real-option settings. ${ }^{2}$

The third article of this issue, by Levaggi and Menoncin (2016), is devoted to tax evasion. The tax compliance literature dates back to the pioneering contribution by Allingham and Sandmo (1972). Since then, it has produced plenty of both positive and normative analyses. In practice, national governments often try to reduce tax evasion by making audits more effective. To this purpose, they use observable and measurable characteristics of taxpayers to target auditing. Recently, predictive analytic tools have become popular. However, in spite of these innovations in audit procedures, most of the theoretical literature still models audit as a process that does not depend on individual spending patterns.

In their paper, Levaggi and Menoncin model tax audit as a stochastic process that depends on individual spending patterns. The authors solve the problem of a representative agent who maximizes the expected present utility of his intertemporal consumption under the assumption that an optimal fraction of her wealth is hidden to the tax authorities. Evasion affects the capital dynamics in two ways: the growth rate of capital increases because some taxes are not paid, but when caught evading the agent has to pay a penalty (proportional to evasion). At each point in time, the agent can allocate consumption expenditure between ordinary goods and so-called conspicuous goods. The latter are used by the government for targeting the tax audit, since they are considered as an indicator of the agent's wealth. The authors find a closed form solution to the dynamic optimization problem and show how fiscal and audit parameters affect tax evasion and the allocation of expenditure between the two types of goods.

This special issue is closed by an article of Mantovi (2016) that addresses the structure of Tyson (2013) conditions for a vector field on consumption space to be a symmetry vector field. The author establishes that symmetry vector fields commute for additive and joint separability, and provides a characterizaztion of symmetry vector

2 See, for example, Panteghini (2007) and Moretto et al. (2015). 
fields in terms of their action on the distance function. A basic pillar of the approach used in this paper is the expansion vector field, introduced by Mantovi (2013) for homothetic models, and given a general stance by Mantovi (2016). Homothetic models embody in many respects the fundamental symmetry of consumers' and producers' problems - one can think e.g. of the factorization of the cost function and the existence of invariant index numbers. A systematic approach to the symmetries of preferences in terms of symmetry vector fields is a promising avenue to further deepen our understanding of the relevance of homothetic models. Furthermore, it may generate insights into still unexploited connections between the building blocks of the theory of the consumer, as shaped for instance by separability problems.

We hope that the readers will appreciate the current special issue and that such a publication will contribute to stimulate further research in this promising area of economic research.

\section{References}

Allingham MG, Sandmo A (1972) Income tax evasion: a theoretical analysis. J Public Econ 1(3-4):323-338

Di Corato L (2016) Investment stimuli under government present-biased time preferences. J Econ. doi:10. 1007/s00712-016-0494-4

Dixit AK, Pindyck RS (1994) Investment under uncertainty. Princeton University Press, Princeton

Levaggi R, Menoncin F (2016) Dynamic tax evasion with audits based on visible consumption. J Econ. doi:10.1007/s00712-016-0493-5

Mantovi A (2013) On the commutativity of expansion and substitution effects. J Econ 110(1):83-105

Mantovi A (2016) Smooth preferences, symmetries and expansion vector fields. J Econ. doi:10.1007/ s00712-016-0475-7

Moretto M, Panteghini PM, Vergalli S (2015) Tax competition, investment irreversibility and the provision of public goods. Ger Econ Rev 16(4):408-421

Panteghini PM (2007) Corporate taxation in a dynamic world. Springer, New York

Panteghini PM, Vergalli S (2016) Accelerated depreciation, default risk and investment decisions. J Econ. doi:10.1007/s00712-016-0500-x

Pennings E (2005) How to maximize domestic benefits from foreign investments: the effect of irreversibility and uncertainty. J Econ Dyn Control 29:873-889

Tyson C (2013) Preference symmetries, partial differential equations, and functional forms for utility. J Math Econ 49(4):266-277 